\title{
Glacifluviálně-glacilakustrinní sedimenty u Vidnavy na severním okraji Žulovské pahorkatiny
}

\author{
Glaciofluvio-glaciolacustrine deposits near Vidnava at the northern margin of the \\ Žulová Hilly Land
}

\author{
Martin Hanáček ${ }^{1} \rightarrow$, Katarína Adameková ${ }^{2}$ \\ 'Vlastivědné muzeum Jesenicka, p. o., Zámecké náměstí 1, 79001 Jeseník, Česká republika \\ 2 Ústav geologických věd, Přrirodovědecká fakulta, Masarykova univerzita, Kotlářská 2, 61137 Brno, Česká republika
}

Key words:

Quaternary, Eastern Sudetes, Elsterian ice-sheet, outwash plain, glaciofluvio-glaciolacustrine environment, grain size

$\square$ geolog@muzeumjesenik.cz, HanacekM@seznam.cz

Editor:

Martin Ivanov
Doporučená citace článku: Hanáček, M., Adameková, K. (2020). Glacifluviálně-glacilakustrinní sedimenty u Vidnavy na severním okraji Žulovské pahorkatiny. Geologické výzkumy na Moravě a ve Slezsku, 27, 1-2, 69-77.

DOI: https://doi.org/10.5817/ GVMS2020-13660

\begin{abstract}
Glaciofluvial and glaciolacustrine sediments were discovered in a small sandpit situated $800 \mathrm{~m}$ SE from Vindava (the Polský kopec Site). Sediments fill two channels located in superposition. Three facies associations (FA) were distinguished in this sedimentary section. The base of the lower channel is formed by gravel lag overlain by gravel-sandy sediments of 3-D dunes and a side bar (FA1). The upper channel infill begins also by basal lag and grades to a fining-upwards sequence from sand to silt (FA2). The sequence is formed from the base up by sediments of small 3-D dunes, A-type ripples, B-type ripples, C-type ripples, and horizontally laminated sediments. The sequence reveals a vertical transition from glaciofluvial (sand) to glaciolacustrine (silt) sedimentation. The sedimentary section is terminated by flat glaciofluvial bedforms (FA3) deposited under upper plane bed conditions. These bedforms arose after the restoration of glaciofluvial conditions. The base of the glaciolacustrine sequence is located at an altitude of $\sim 275 \mathrm{~m}$ as well as the Old Kaolin Mine Site ( $850 \mathrm{~m}$ SW from the Polsky kopec Site) where very similar sediments have been already described. The sediments of both localities represent a proglacial outwash plain in front of the retreating ice sheet (FA1 consists of $\sim 23 \%$ of erratic rocks), where a relatively large lake, or a system of smaller lakes evolved at the same time.
\end{abstract}

\section{Úvod a lokalita}

Jihovýchodně od Vidnavy se na ploše $3,75 \times 2 \mathrm{~km}$ rozkládá téměř souvislá akumulace sedimentů elsterského pevninského zalednění (Žáček et al. 2004). Zachovala se na mírně zvlněném severním okraji Žulovské pahorkatiny, která se v těchto místech nápadně zvedá nad Vidnavskou nížinu (obr. 1A). Ledovcové sedimenty spočívají na žulovském masivu, konkrétně bud' na pevných granitoidech nebo na kaolínu (obr. 1B). Granitoidní elevace preglaciálního reliéfu místy podmínily vznik glacitektonitů a melt-out tillů a rovněž ohraničovaly terénní deprese, vyplněné podledovcovými deltami či subakvatickými kužely (Hanáček et al. 2016). V jihozápadní části sedimentární akumulace jsou nad granitoidy glacifluviální písky, faciálně odpovídající distálním částem výplavových plošin (Hanáček 2017). Opěrnou lokalitou pro výzkum ledovcových sedimentů je Stará kaolínová jáma $1 \mathrm{~km}$ jižně od Vidnavy s relikty subglaciálního tillu, glacifluviálními a glacilakustrinními sedimenty (Kiegler 1938; Gába 1992; Hanáček 2008, 2017). Báze ledovcových sedimentů zde leží přibližně v $270 \mathrm{~m} \mathrm{n.} \mathrm{m.}$

Zhruba $800 \mathrm{~m}$ jv. od Vidnavy leží malá $(50 \times 40 \mathrm{~m})$, dávno opuštěná a vegetací zarostlá pískovna $v$ nadmořské výšce $270-276 \mathrm{~m}$ n. m, která dosud nebyla faciálně zpracována. Pískovna se nachází na východním okraji městské 

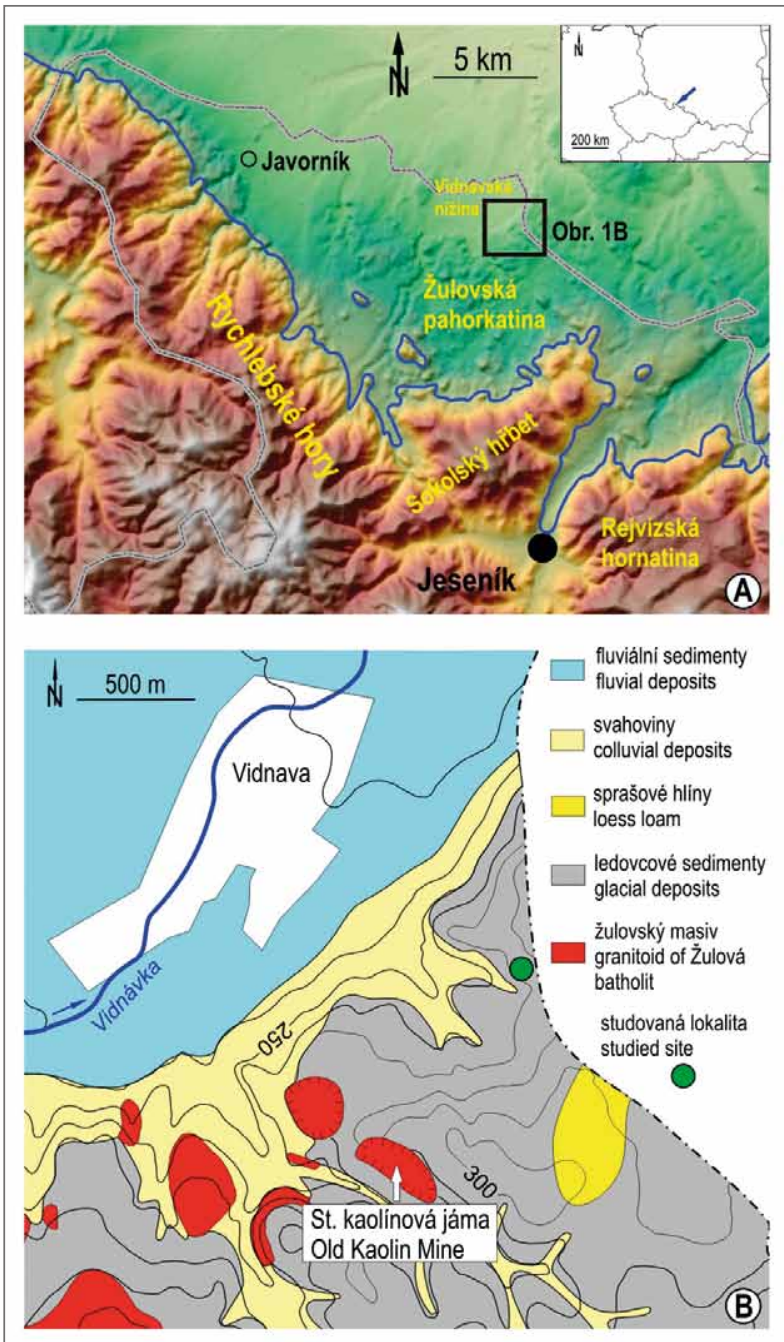

Obr. 1: A. Topografická poloha studovaného území. Modře: maximální hranice elsterského ledovcového štítu (podle Nývlta et al. 2011). B. Zjednodušená geologická mapa studované oblasti s polohou pískovny na Polském kopci (zelený kroužek). Upraveno podle Žáčka et al. (2004).

Fig. 1: A. Topography of the study area. Blue: maximum extent of Elsterian ice-sheet (according to Nývlt et al. 2011). B. Simplified geological map of the study area with the location of Polský kopec sandpit (green circle). Modified fromŽáček et al. (2004).

skládky, v jižním svahu návrší neformálně nazývaného "Polský kopec“ (GPS souřadnice lokality: 50,3664574 N, 17,1992463 E). Polský kopec dosahuje na českém území výšky $284 \mathrm{~m}$ n. m., přičemž nad úrovní pískovny je celý budován štěrkopískovými ledovcovými (převážně pravděpodobně glacifluviálními) sedimenty. Na temeni pahorku, u státní hranice s Polskem, byly tyto sedimenty odkryty výkopem pro vodojem. Odkryv nakonec zanikl bez dokumentace. V blízkém jižním okolí Polského kopce dosahují ledovcové sedimenty do nadmořské výšky až $310 \mathrm{~m}$, což dokazuje poloha bývalých pískoven i Staré kaolínové jámy a rovněž plošný povrchový výskyt eratik.

Mezi lety 2011 a 2012 byl v severovýchodní stěně pískovny na Polském kopci dočasně odkryt profil o šířce $\sim 10 \mathrm{~m}$ a výšce $\sim 5 \mathrm{~m}$, který se $\mathrm{v}$ uvedeném období podařilo sedimentologicky zpracovat. Předložený př́spěvek se zaměřuje na faciální analýzu, granulometrii a petrograficko-provenienční analýzu štěrkové frakce sedimentárního záznamu $\mathrm{z}$ dočasně odhalené severovýchodní stěny pískovny. Jelikož se zkoumaná stěna téměř kompletně zhroutila a odkryv je navíc zavážen odpadem, představuje předložený článek výsledky záchranného výzkumu v podstatě zaniklé lokality. Zjištěné výsledky obohacují regionální poznání pleistocénu.

\section{Metodika}

V sedimentech byly na základě makrotextur vyčleněny facie a tyto podle svých prostorových souvislostí spojeny do faciálních asociací (Zieliński 1993). Genetická interpretace facií vychází z literatury citované dále. Paleoenvironmentálně nejzajímavější část profilu byla analyzována granulometricky (podle klasifikace Wentwortha 1922) a výsledky jednotlivých facii byly vzájemně srovnány. Rovněž facie bezprostředně pod zmíněnou sekvencí byly zrnitostně analyzovány kvůli vzájemnému srovnání. Zrnitostní analýza byla provedena metodou sítování za mokra na normovaných sítech (Retsch AS - 200) v kombinaci s laserovou a optickou metodou provedenou na pŕístroji Bettersize S3 Plus. Vzorky byly dispergovány $\mathrm{v}$ roztoku destilované vody $s$ použitím hexametafosforečnanu sodného. U vzorků $s$ minimálním podílem jílovo-siltové komponenty (pod $5 \%)$ nebyla tato komponenta detailně analyzována a v zrnitostních grafech je shrnuta do kategorie F (fines). Vzorek pro valounovou analýzu byl separován lopatkou a normalizovanými síty $\mathrm{z}$ facie s nejvyšším podílem štěrku. Zvolená frakce 16-64 mm je reprezentativní pro štěrkovou složku zkoumaných sedimentů, a navíc lze klasty této frakce spolehlivě determinovat. K určování hornin byly užity geologické mapy a jejich vysvětlivky (Žáček et al. 2004) a dále specializovaná literatura (Gába, Pek 1999). Zaoblení bylo stanoveno podle škály Powerse (1953). Pro zjištění orientace zvrstvení/laminace byly změřeny tři různě početné sady vrstev/lamin (10-24 údajů v každé sadě podle odkrytosti facií a také podle pozorovatelné proměnlivosti orientace).

Obr. 2: A. Log I - celkový log sv. stěnou pískovny na Polském kopci včetně grafů orientace zvrstvení/laminace. B. Log II - log profilem na kontaktu FA1 a FA2 včetně grafů zrnitosti. C. Svrchní část odkryté stěny s kompletní architekturou FA2. Nápadné je deskovité těleso jemnozrnných glacilakustrinních sedimentů. Měřítko: $1 \mathrm{~m}$. D. FA2: složený set facií St, Sr v nadloží bazálního lagu a v podloží jemnozrnných glacilakustrinních sedimentů. E. FA2: Facie Src a Fw (přechod z čeřin typu A přes čeřiny typů $\mathrm{B}$ a $\mathrm{C}$ do zvlněné laminace). F. FA2: facie $\mathrm{Fh}$ - horizontálně laminované glacilakustrinní silty. Měŕítko: $5 \mathrm{~cm}$. $\mathrm{H}$. FA3: facie Sh s vloženou facií Sr.

Fig. 2: A. Log I - general log of the sedimentary sequence situated at the north-eastern wall of the Polský kopec sandpit including graphs of bedding/lamination orientation. B. Log II - the contact of FA1 and FA2 including graphs of grain-size distribution. 


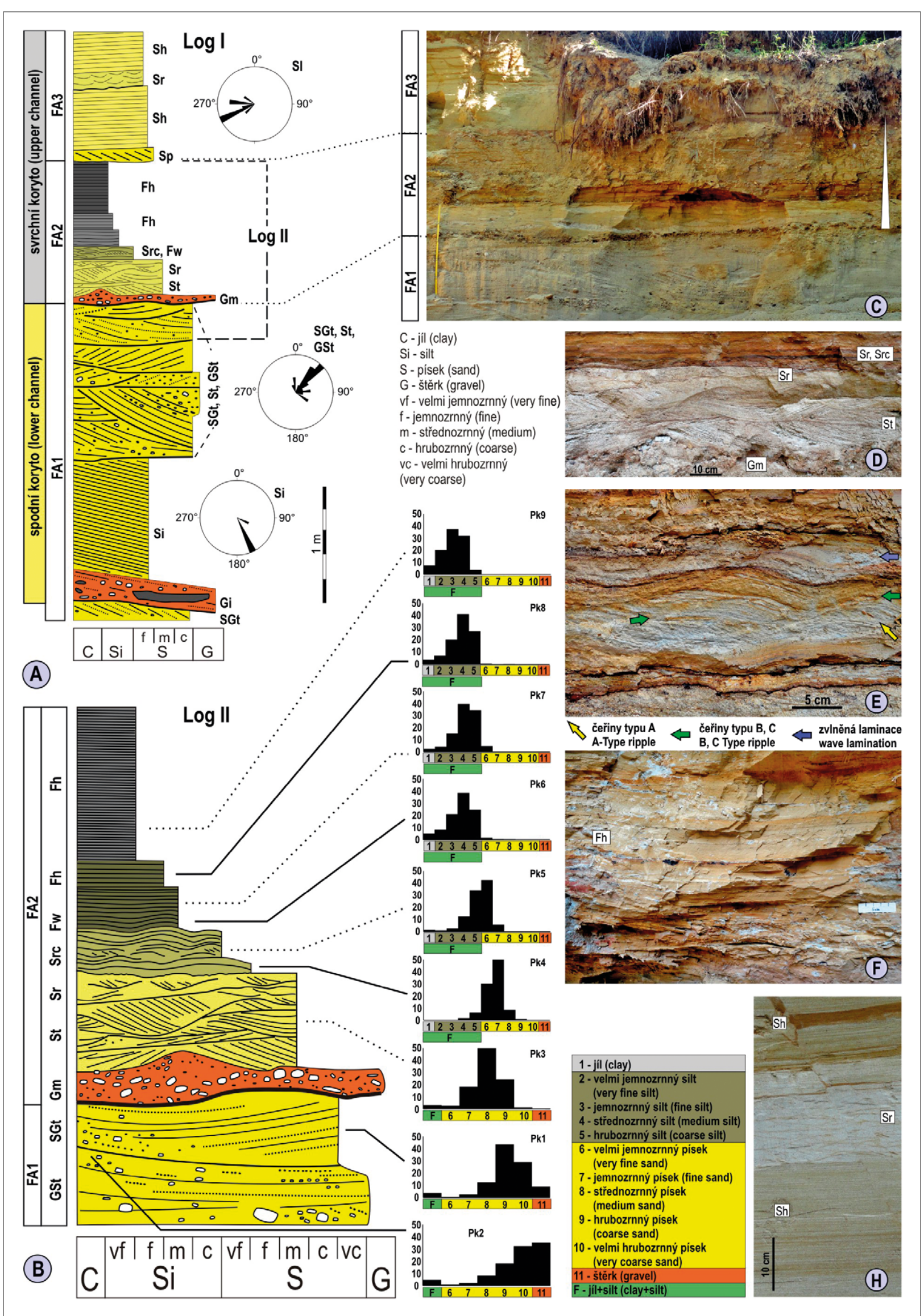

$\vec{G}$ C. The upper part of the exposed wall with the complete FA2 architecture. The platy body of fine-grained glaciolacustrine sediments is conspicuous. Scale: $1 \mathrm{~m}$. D. FA2: a co-set of St, Sr facies in the overlying of the basal lag and in the underlying of fine-grained glaciolacustrine sediments. E. FA2: Src and Fw facies (transition from A-type ripples through B and C-type ripples to wavy lamination). F. FA2: Fh facies - horizontally laminated glaciolacustrine silts. Scale: $5 \mathrm{~cm}$. H. FA3: Sh facies with interbedded $\mathrm{Sr}$ facies. 


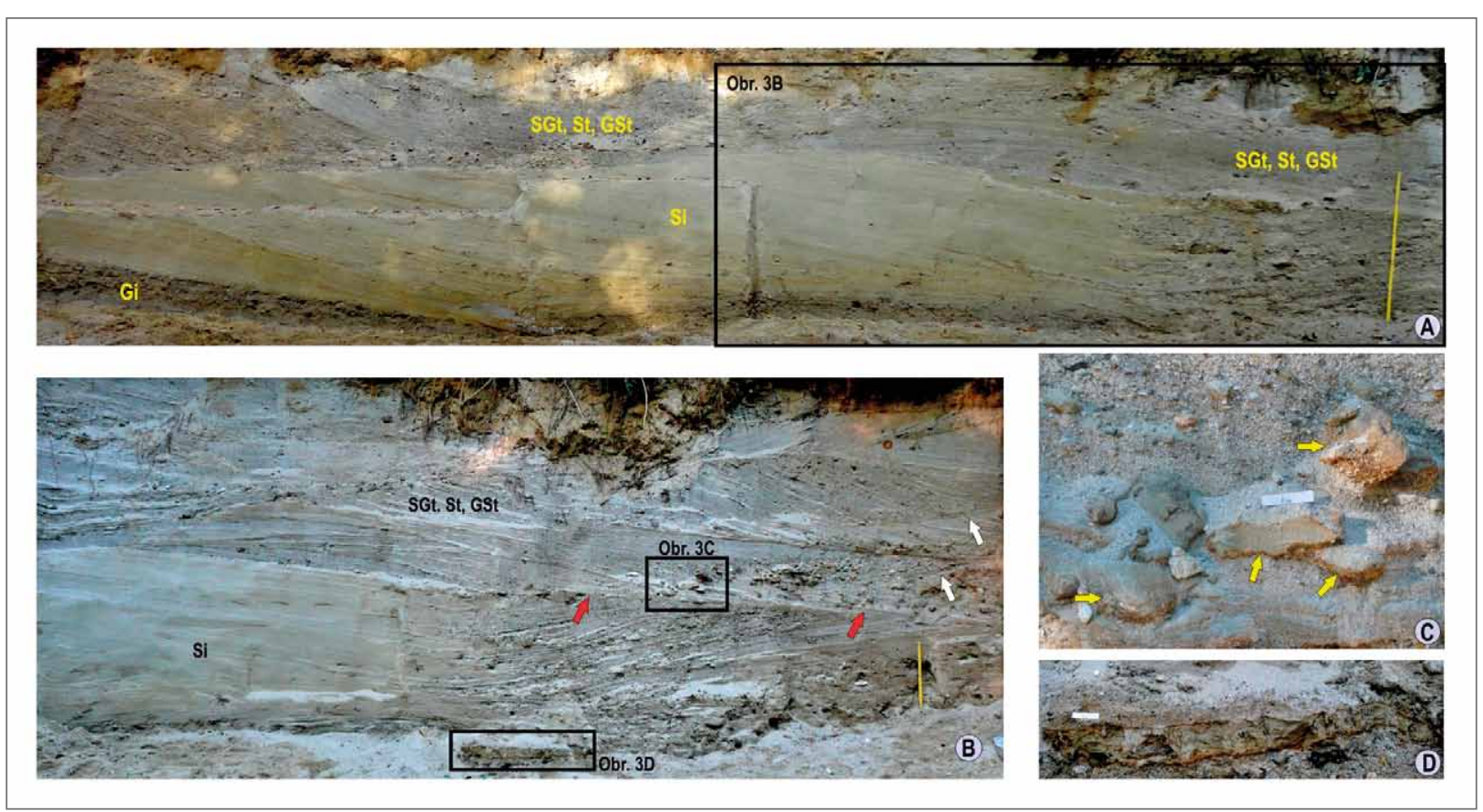

Obr. 3: Faciální asociace 1. A. Laterálně rozsáhlý set facie Si (sedimenty postranního valu) a sety facie SGt, St a GSt (3-D duny v korytě). Měřítko: $1 \mathrm{~m}$. B. Prstovité prolínání facií Si, SGt, St a hraniční povrchy v rámci složených setů facií SGt, St a GSt (šipky, viz text). Měřítko: $40 \mathrm{~cm}$. C. Intraklasty jílovitoprachovitých sedimentů (žluté šipky) ve facii SGt. Měřítko: $5 \mathrm{~cm}$. D. Největší intraklast jílovitoprachovitých sedimentů $(70 \times 8 \mathrm{~cm})$ ve facii Gi. Měrítko: $5 \mathrm{~cm}$.

Fig. 3: Facies association 1. A. Laterally extensive set of Si facies (side bar deposits) and sets of SGt, St and GSt facies (3-D dunes in the channel). Scale: $1 \mathrm{~m}$. B. Interfingering of the Si, SGt and St facies and boundary surfaces within the co-sets of the SGt, St and GSt facies (arrows, see text). Scale: $40 \mathrm{~cm}$. C. Intraclasts of clayey-silty sediments (yellow arrows) in the SGt facies. Scale: $5 \mathrm{~cm}$. D. The largest intraclast of clayey-silty sediments $(70 \times 8 \mathrm{~cm})$ in the Gi facies. Scale: $5 \mathrm{~cm}$.

\section{Výsledky}

Přes prostorovou omezenost odkryté stěny $\mathrm{v}$ pískovně bylo v sedimentech vyčleněno 13 facií, sdružených do 3 faciálních asociací.

\section{Faciální asociace 1 (FA1)}

FA1 tvoří spodní polovinu profilu (obr. 2A) a dosahuje mocnosti $\min .350 \mathrm{~cm}(280 \mathrm{~cm}$ ve stěně plus dalších $\sim 75 \mathrm{~cm}$ v sondách na dně odkryvu, přičemž báze nebyla dosažena). Skládá se z těchto facií: korytovitě zvrstvené štěrkovité písky (SGt), korytovitě zvrstvené písky (St), korytovitě zvrstvené písčité štěrky (GSt), písky s ukloněnou laminací (Si) a písčité štěrky s neprůběžným ukloněným zvrstvením (Gi).

Těsně nad bází profilu se šikmo uklání deskovitá poloha facie Gi o mocnosti $20 \mathrm{~cm}$ (obr. 3A). Obsahuje intraklasty (tzv. obrněné závalky) jílovitosiltovitých masivních i laminovaných sedimentů, zaobleného diskovitého a kulovitého tvaru. Velikost závalků většinou nepřekračuje $10 \mathrm{~cm}$. Výjimkou je jeden intraklast o délce $70 \mathrm{~cm}$ a mocnosti max. $8 \mathrm{~cm}$ (obr. 3D). Nad facií Gi je vyvinuto klínovité těleso facie Si s laterálním rozsahem min. $8 \mathrm{~m}$ a maximální zachovalou výškou $130 \mathrm{~cm}$ (obr. 3A). Laminy upadají pod úhly $9-12^{\circ}$ na $\mathrm{JV}$, v rozpětí $112-157^{\circ}$, většinou $152-157^{\circ}$ (obr. $\left.2 A\right)$. Spodní hranice vůči facii Gi je celkově ostrá, ale neerozní, ovšem místy se štěrkové vrstvy facie Gi a laminy tělesa Si zastupují.

Vpravo se facie Si zřetelně prstovitě prolíná s faciemi SGt a St (obr 3B). Facie SGt, St a vzácněji GSt zaujímají celou svrchní polovinu FA1 a jsou protnuty dvěma typy rozhraní (obr. 3B). Hierarchicky významnější jsou rovná ukloněná rozhraní (červené šipky v obr. 3B), která vymezují složené sety čočkovitých těles s výmolovými bázemi (bílé šipky v obr. 3B). Tyto výmolové báze ohraničují šikmo zvrstvené sety dílčích facií a představují hierarchicky nižší povrchy. Výmolovými bázemi seřezávají sety facií SGt a St svrchní povrch klínovitého tělesa facie Si (obr. 3A). Mocnost jednotlivých setů se pohybuje mezi 20 a $50 \mathrm{~cm}$. Ve faciích GSt, SGt a St se tenké vrstvy mocné kolem $10 \mathrm{~mm}$ střídají s laminami mocnými několik mm, často $5 \mathrm{~mm}$. Podíl laminace roste v čistě pískových faciích, v nichž se stř́idají laminy hrubozrnného a střednozrnného písku. Štěrkové vrstvy ve faciích GSt a Gi tvoří hlavně štěrčík a drobné klasty, většinou do $1 \mathrm{~cm}$ velikosti. Větší klasty (do $10 \mathrm{~cm}$ v a-ose) představují akcesorii. V některých setech facie SGt se změnami v podílech větších klastů projevuje pozitivní nebo negativní gradace. Zvrstvení/ laminace facií GSt, SGt a St upadá pod úhly $8-26^{\circ} \mathrm{v}$ širokém rozmezí orientací $26-352^{\circ}$, ovšem převážně na $\mathrm{SV}$, v rozpětí $26-82^{\circ}$ (obr. $2 \mathrm{~A}$ ). Facie SGt a GSt obsahují lokálně hojné intraklasty (obrněné závalky) zaobleného tvaru o velikosti do $10 \mathrm{~cm}$ (obr. $3 \mathrm{C}$ ), shodné s intraklasty ve facii Gi.

Nejpočetnější skupinou klastů v FA1 (facie GSt) jsou horniny nordické provenience (vápence, granitoidy, porfyry, ruly, kvarcity, pískovce, pazourky), tvořící 22\% materiálu. Následují horniny provenienčně určitě nebo pravděpodobně spjaté s hlavním hřebenem Rychlebských 
hor: šedě, bělošedě zbarvená rula gierałtowského typu $\sim 21 \%$, amfibolit+metagabro $\sim 10,5 \%$, dále grafitický, muskovitický i živcový kvarcit a svor (každá z hornin 1-2\%), blíže neurčené metamorfity rulového vzhledu ( 15\%). Granitoidy vzhledově shodné s žulovským masivem tvoří jen $\sim 3 \%$ klastů. Polské horniny (sudetský porfyr, lydit) jsou zastoupeny pouze $\sim 1 \%$. Křemen zaujímá $~ 18 \%$ klastů. Zaoblení je rozloženo následovně: suboválné: $60 \%$, subangulární $23 \%$, oválné $10,5 \%$, angulární $4,2 \%$, dokonale oválné $2,3 \%$.

\section{Faciální asociace 2 (FA2)}

FA 2 zaujímá polovinu svrchní části profilu a dosahuje mocnosti $\sim 130 \mathrm{~cm}$ (obr. $2 \mathrm{~A}, \mathrm{~B}, \mathrm{C}$ ). Skládá se z těchto facií: masivní štěrk $(\mathrm{Gm})$, korytovitě zvrstvený až laminovaný písek s mocností těles kolem $10 \mathrm{~cm}(\mathrm{St})$, písek s šikmou laminací malé škály (mocnost do $5 \mathrm{~cm}$ ) a výmolovými bázemi (Sr), siltovitý písek s asymetrickou zvlněnou laminací ( $\mathrm{Src}$ ), silty se symetrickou zvlněnou laminací (Fw) a horizontálně laminované silty (Fh).

Bázi FA2 vyznačuje laterálně stálá poloha facie Gm $s$ proměnlivou mocností mezi 5 a $10 \mathrm{~cm}$ (obr. 2B). Převládají klasty o velikosti do $1 \mathrm{~cm}$, vzácně $10 \mathrm{~cm}$ v a-ose. Mezi nimi je směs hrubozrnného písku až štěrčíku. Laterální rozsah facie překračuje hranice odkryvu $(\sim 10 \mathrm{~m})$, viz obr. $2 \mathrm{C}$.

Facii Gm v celém jejím laterálním rozsahu pokrývá až $25 \mathrm{~cm}$ mocné deskovité, velmi mělce zahloubené těleso (složený set), tvořené faciemi St a Sr (obr. 2A, B, C). Kontakt s facií Gm je ostrý, ale neerozní, laminace facií St a $\mathrm{Sr}$ se přikládají k nerovnému povrchu facie Gm (obr. 2D). Těleso je složeno $z$ dílčích setů, vzájemně se seřezávajících mělkými i výrazně zahloubenými výmolovými bázemi. V setech se střídají laminy hrubo-a střednozrnného, méně jemnozrnného písku. Mocnost setů ve spodní části složeného setu dosahuje až $12 \mathrm{~cm}$ (facie St), ale občas dochází od báze nahoru $\mathrm{k}$ postupnému zmenšování až na sety mocné $2-5 \mathrm{~cm}$ (facie $\mathrm{Sr}$ ), viz obr. $2 \mathrm{~B}, \mathrm{D}$. V těchto malých setech převažují laminy středno- a jemnozrnného písku.

V nadloží cosetu facií St, Sr se charakter sedimentů náhle mění, protože se stávají výrazně jemnozrnnými a relativně kompaktními. Tyto sedimenty tvoří deskovité těleso o mocnosti $90 \mathrm{~cm}$ se shodným laterálním rozsahem jako tělesa podložních facií St, Sr a Gm (obr. 2C). Faciálně se jemnozrnné těleso vyvíjí takto (obr. $2 \mathrm{~B}, \mathrm{E}$ ): těsně nad bází je zřetelně průběžná asymetricky zvlněná laminace, vyznačující se agradací zvlněných lamin pod příkře šikmým úhlem (facie Src). Místy se ve spodní části této facie nacházejí čočkovitá tělesa s šikmou laminací malé škály. Výše se šikmá agradace zvlněných lamin mění na vertikální agradaci (facie Fw). Zhruba $15 \mathrm{~cm}$ nad bází pak zvlněná laminace facie Fw přechází do horizontální laminace facie $\mathrm{Fh}$. Facie Fh, s laminami mocnými desetiny $\mathrm{mm}$ až $5 \mathrm{~mm}$, představuje zbylých $\sim 75 \mathrm{~cm}$ mocnosti jemnozrnného tělesa (obr. 2F).

\section{Faciální asociace 3 (FA3)}

FA3 se nachází ve svrchní třetině zkoumané stěny a plochou bází překrývá podložní facii Fh (obr 2A, C).
Laterální rozsah přesahuje hranice profilu (min. $10 \mathrm{~m}$ ) a minimální mocnost činí $150 \mathrm{~cm}$. Svrchním ohraničením FA3 je povrch terénu, takže úplnou mocnost neznáme. Asociace se skládá $\mathrm{z}$ těchto jemno-střednozrnných pískových facií: planárně šikmo laminovaný písek (Sp), subhorizontálně laminovaný písek (Sh) a písek s korytovitou laminací malé škály a výmolovými bázemi setů (Sr).

Nejnižším členem je až $11 \mathrm{~cm}$ mocné těleso facie $S p$, vyplňující mělkou depresi v podložní facii Fh. Následuje $\sim 60 \mathrm{~cm}$ mocný set facie $S h$, jehož laminy se pod úhly $3-5^{\circ}$ uklánějí k ZSZ, Z, ZJZ (222-307º, obr. 2A). Laminy jsou mocné 3-5 mm. Na facii Sh nasedá rovným ukloněným povrchem složený set facie $S r$ o mocnosti $\sim 15 \mathrm{~cm}$ (obr. $2 \mathrm{H}$ ). Je složen $z$ dílčích, šikmo laminovaných setů o mocnosti $1-2 \mathrm{~cm}$. Tyto sety se vzájemně seřezávají výmolovými bázemi. Na složený set facie Sr navazuje přímou bází další set facie Sh. Kvůli své mělce podpovrchové pozici je různě deformován (vyplněné pukliny, porušení laminace, zvětrání), pročež nebyl podrobněji studován včetně měření orientace lamin. Mocnost setu je min. $50 \mathrm{~cm}$.

\section{Zrnitostní vývoj intervalu: svrchní část FA1-FA2}

Zrnitostní trend na rozhraní FA1 a FA2 lze sledovat v logu II na obr. 2B. Podstatnými složkami facií GSt a St ve svrchní části FA1 jsou hrubé pískové frakce a štěrk. Ve facii St (vzorek Pk1) převládají hrubozrnný písek ( 44\%) a s mírným odstupem velmi hrubozrnný písek ( 29\%). Střednozrnný písek zaujímá $12 \%$, jemnější pískové frakce se pohybují v prvních procentech. Štěrk tvoří $\sim 9 \%$. Ve facii GSt (vzorek Pk2) dominují štěrk ( 35\%) a velmi hrubozrnný písek ( 32\%). Hrubozrnný písek představuje $\sim 18 \%$ a podíly středno i jemnozrnného písku se pohybují v prvních procentech. Společným znakem facií GSt a St je zanedbatelná siltovo+jílová komponenta, jejíž podíly se pohybují mezi 3,5 a 4,5\%.

Ve facii St uvnitř FA2 (vzorek Pk3) dominuje střednozrnný písek ( 50\%). Hrubozrnný písek ( 24\%) a jemnozrnný písek $(\sim 18 \%)$ jsou další podstatné složky. Ostatní frakce se pohybují mezi desetinami procent až prvními procenty (silt+jíl 3,3\%).

Ve facii Src je zřetelný vertikální nárůst role siltů. Spodní vzorek Pk4 obsahuje hlavně jemnozrnný písek ( 52\%) a velmi jemnozrnný písek ( 30\%). Silt je stále menšinový: hrubozrnný silt $\sim 6 \%$, střednozrnný silt necelá $2 \%$. Svrchní vzorek Pk5 obsahuje již jen necelých $6 \%$ jemnozrnného písku, ale $\sim 43 \%$ velmi jemnozrnného písku, a zejména $34 \%$ hrubozrnného siltu a $12,5 \%$ střednozrnného siltu.

Zjemňující trend pokračuje výše ve facii Fw. Ve spodním vzorku této facie (Pk6) již téměř chybí písek a složení je hlavně siltové: střednozrnný silt $~ 39 \%$, hrubozrnný silt $\sim 25 \%$, jemnozrnný silt $\sim 21 \%$, velmi jemnozrnný silt $\sim 8 \%$. Poprvé v celé granulometricky studované sekvenci podstatněji přibývá jílu ( $5 \%)$. Následující svrchní vzorek facie Fw (Pk7) a spodní vzorek facie Fh (Pk8) se vzorku Pk6 velmi podobají. Nejjemnozrnnější je pak svrchní vzorek facie Fh (Pk9): jemnozrnný silt 37\%, střednozrnný silt $\sim 32 \%$, velmi jemnozrnný silt $\sim 20 \%$, hrubozrnný silt jen $\sim 3,5 \%$. Jíl zaujímá téměř $\sim 7,5 \%$. 


\section{Interpretace a diskuze Geneze facií}

Tenká deskovitá poloha facie Gi představuje štěrkový lag, vzniklý za nejsilnějšího proudění, kdy byl písčitý materiál odnesen a na dně koryta zbyla pouze nejhrubší frakce (Pisarska-Jamroży, Zieliński 2014). Kvantitativně nejdůležitější sedimenty FA1(facie SGt, GSt a St) jsou dle mocnosti tělesa střední škály a představují sedimentární záznam poproudové akrece 3-D dun na dně dobře definovaného fluviálního koryta (Zieliński 1993). Proud byl dostatečně silný $\mathrm{k}$ trakci štěrku a saltaci písku. Siltová a jílová frakce zůstávaly během migrace dun rozptýleny ve vznosu a byly unášeny silným prouděním, čemuž nasvědčuje minimální podíl těchto frakcí ve vzorcích PK1 a PK2 i celkově dobře vytříděný charakter sedimentů.

Zcela odlišná je facie Si, která se vyznačuje jemno-střednozrnností a mnohem mírnějším sklonem laminace. Podobné sedimenty (písky s nízce ukloněným zvrstvením/laminací) vznikají v korytech s př́ičnými lavicemi, kdy v závislosti na hloubce rostou lavice bud's vysokými nebo nízkými čely (Zieliński 1993). Sedimentární záznam tohoto prostředí se vyznačuje střídáním šikmo planárně zvrstvených facií o velkém i nízkém sklonu vrstev (Zieliński 1993; Salamon 2008; Pisarska-Jamroży 2015). Zde popisovaná facie Si je však asociována s odlišnými sedimenty. Spočívá na ukloněném štěrkovém lagu (reziduální pokrývce dna koryta) a zejména se nápadně prstovitě laterálně prolíná s korytovými faciemi SGt a St (obr. 3A, B). Podobný laterální vztah byl popsán ze sedimentů proglaciální plošiny v jižním Polsku jako příčný průřez výplní ohybu fluviálního koryta, v němž nízce ukloněné písky sedimentovaly na vnitřní straně ohybu, zatímco kory tovitě zvrstvené písky na vnější straně ohybu (Zieliński 1992). Analogicky proto facie Si představuje laterálně, nebo laterálně-poproudově akretované sedimenty vnitřní, nízkoenergetické strany ohybu koryta (side bar, point bar deposits podle Bridge 2003) a facie SGt a St jsou záznamy 3-D dun v linii proudnice, podél vnější strany ohybu koryta. Interpretaci podporuje i orientace zvrstvení/laminace, které v korytovitých faciích upadá s různými variacemi $\mathrm{k} S \mathrm{~V}$, zatímco ve facii Si uniformně k JV (obr. 2A). Směry jsou na sebe kolmé, což koreluje $s$ představou koryta, $v$ němž 3-D duny poproudově migrovaly osou koryta k SV, zatímco postranní lavice akretovala kolmo na duny, laterálně od vnějšího břehu do osy koryta. Bohužel v době výzkumu nebylo změřeno zvrstvení v konkrétních tělesech SGt a St, prrímo laterálně navazujících na těleso Si. Převážně severovýchodní orientace dalších laterálních i nadložních 3-D dun však umožňují předpokládat generální směr poproudové akrece na SV. Široký rozptyl hodnot je pro korytovité facie charakteristický kvůli trojrozměrnému tvaru dun a lokálním změnám proudění mezi dunami a přilehlými výmoly (Zieliński 1992).

V nadloží výplně ohybu koryta následují složené sety korytovitě zvrstvených facií s rozhraními dvojí hierarchie. Tato stavba vzniká vyplňováním koryt i sedimentací na přilehlých valech (Miall 1985; Bridge et al. 1986; Blažauskas et al. 2007; Salamon 2008; Pisarska-Jamroży
2015). Omezená odkrytost architektury ale neumožňuje detailnější interpretace.

Iniciálním procesem, předcházejícím depozici sedimentů FA2, byla fluviální eroze, která zničila reliéf dun a depresí v korytě. Většina písčitých sedimentů byla odplavena a nejhrubší frakce (facie $\mathrm{Gm}$ ) zůstala jako reziduální štěrkový lag, pokrývající dno koryta (Pisarska-Jamroży, Zieliński 2014). Mezihmota lagu vznikla uvíznutím písku a štěrčíku mezi stacionární valouny, kde byly drobné frakce uchráněny před odnosem (Smith 1974). Jelikož lag vznikl erozí dřive uložených dun i prrísunem nového materiálu, nebyl granulometricky zkoumán jako facie $\mathrm{v}$ jeho podloží a nadloží, protože tyto facie jsou výsledkem pouze depoziční aktivity a jsou tak vzájemně srovnatelné. Po poklesu energie toku se písek začal ukládat ve formě poproudově migrujících 3-D dun (facie St) a s dalším poklesem proudění do $3-\mathrm{D}$ čeřin typu A (facie $\mathrm{Sr}$ ). Tento trend ovšem neexistoval zcela plošně v celém korytě, ale spíše jen místy, protože ne ve všech úsecích je zjevný vertikální vývoj z facie St do facie Sr. Nadložní facie Src zaznamenává přechod $\mathrm{z}$ dominantně písčité poproudové saltační sedimentace (duny, čeřiny typu A) do příkře agradující suspenzní sedimentace čeřin typu B a C (Jopling, Walker 1968). Změnu depozičního procesu dobře dokumentuje zrnitostní vývoj facií v sekvenci St, Sr-Src, vyznačující se poklesem podílu písku a výrazným nárůstem podílu siltu (obr. 2B). Přechod do suspenzní sedimentace pokračuje dále ve facii Fw, složené hlavně ze středno- a hrubozrnného siltu. Je završen ve facii Fh $s$ převahou jemnozrnného, střednozrnného a velmi jemnozrnného siltu, s nejvyšším podílem jílu. Sedimentární sled FA2 tedy archivuje změnu z fluviálního do jezerního prostředí.

Faciální asociace 3 nastupuje $10 \mathrm{~cm}$ mocným tělesem Sp, které vzniklo poproudovou akrecí nevysoké 2-D duny (př́ičné lavice, Zieliński 1993) po nevýrazně erozně modifikovaném povrchu facie Fh. Následné stř́íání facií Sh-Sr-Sh dokazuje prrítomnost mělkého koryta, po jehož plochém dně byl písek posunován formou velmi protáhlých, ale nízkých dnových forem, které se morfologicky prakticky neprojevují (podmínky typu upper plane bed podle Miall 1996; Bridge 2003). Pouze za dočasného zpomalení proudu začaly na dně růst a migrovat drobné čeřiny typu A (Jopling, Walker 1968).

\section{Depoziční prostředí}

Petrografie valounů v FA1 umožňuje spojit genezi studovaných sedimentů s pevninským zaledněním. Nordické a polské (souhrnně eratické) horniny tvoří 23\% materiálu, což je prŕliš vysoký podíl na postglaciální fluviální sedimenty, ve kterých tyto klasty, resedimentované $\mathrm{z}$ ledovcových uloženin, představují pouhé akcesorie (Žáček et al. 2004). Necelá pětina eratik v sedimentech tvoří značný podíl i ve srovnání s jinými ledovcovými uloženinami v předpolí Rychlebských hor a Rejvízské hornatiny (Gába 1974; Hanáček 2014).

Podle provenience materiálu a sedimentárních textur se jedná o glacifluviální a glacilakustrinní sedimenty. Tyto mohou existovat ve vztahu k ledovci ve všech 
pozicích. Supraglaciální a englaciální pozici nepodporuje absence deformací, které by v sedimentech způsobila degradace podložního nebo okolního ledovce (Brodzikowski, van Loon 1991). Pro rozlišení mezi proglaciálním, terminoglaciálním a subglaciálním prostředím jsou klíčové jezerní facie Fw, Fh. Subglaciální pozici vylučuje absence jednotlivých větších klastů ve faciích Fw a Fh, které by roztávání uvolnilo z bazálního ledu, tvořícího strop potenciální kavity, a jež by zapadly do jemnozrnných glacilakustrinních sedimentů jako dropstony (Gibbard 1980). Absence dropstonů i shluků větších klastů (dumpstonů) ve faciích Fw a Fh neukazuje ani na blízký kontakt jezera s čelem ledovce, $\mathrm{z}$ něhož by se do jezera odlamovaly ledové kry (Pisarska-Jamroży et al. 2018). Depoziční prostředí bylo tedy situováno v proglaciální pozici. Glacifluviální sedimenty proglaciální zóny pevninského ledovce ve střední Evropě nejpodrobněji rozdělují Zieliński a van Loon (2003). Podle jejich klasifikace odpovídá FA1 facii D-2 (výplně sekundárních koryt distální části divočící plošiny), většina FA2, vyjma bazálního lagu, odpovídá facii D-5 (sedimenty fluktuujících, převážně nízkoenergetických proudů až stagnující vody, vyplňující sekundární koryta na okraji výplavové plošiny) a FA3 odpovídá rovněž facii D-5 s určitými prvky facie D-4 (výplně mělkých širokých koryt distálního úseku výplavové plošiny). Nejsilnější proudění deponovalo FA1 a stagnující voda facie Fw a Fh v FA2.

Faciální analýza umožňuje v profilu odlišit výplně dvou koryt v superpozici. Erozní báze koryt pokrývají štěrkové lagy (facie Gi, Gm). Spodní koryto vyplňuje FA1 složená kromě převažujících poproudově akretujících dnových forem i z laterálně akretující dnové formy. Glacifluviální sedimenty vznikají převážně v divočícím říčním stylu (Brodzikowski, van Loon 1991). Pro ten jsou typické poproudově akretující vnitrokorytové valy a výplně koryt, zatímco laterálně akretující postranní valy jsou v menšině (Smith 1974; Miall 1977; Colombera et al. 2013). Laterální akrece je naopak zásadním depozičním procesem meandrujících řek (architekturní prvek LA, Miall 1985). Mezi divočícími a meandrujícími řekami však existují přechodné styly (Bristow 1996) a ohyby koryt s laterálně i poproudově akretovanými valy a výplněmi koryt jsou známé rovněž z písčitých divočících řek (Bridge et al. 1986, 1998). $\mathrm{K}$ přechodu $\mathrm{z}$ divočícího do meandrujícího stylu docházelo při změně z široké výplavové plošiny s mnoha laterálně nestabilními koryty do řeky vroubící okraj ledovce a mající jasněji definované koryto (ice-marginal river podle Blažauskase et al. 2007). Poproudové i vertikální přechody mezi divočícím a meandrujícím stylem byly doloženy i z proglaciálních výplavových plošin jižního Polska (Salamon 2008). Jelikož podle srovnání s faciálním vývojem proglaciálních sandrů (Zieliński, van Loon 2003) náleží FA1 sekundárním kanálům distální zóny divočící plošiny, byla patrně vyšší sinuosita spodního koryta projevem složitějšího větvení a klikatění koryt $\mathrm{v}$ postranním úseku plošiny, vzdáleném od nízce sinuosních hlavních koryt.

Svrchní koryto vyplňují FA2 a FA3. Nahoru zjemňující sekvence facií St-Sr-Src-Fw-Fh byla v různých obdobách popsána $\mathrm{z}$ distálních částí výplavových plošin (Zieliński 1989, 1993; Zieliński, van Loon 2003; Blažauskas et al. 2007). Odpovídá faciálnímu rytmu Sr-STx, zaznamenávajícímu přechod ze saltační do suspenzní sedimentace v proglaciálních sandrech (Pisarska-Jamroży, Zieliński 2014). Podle citovaných autorů se jedná o výplně postranních koryt výplavových plošin zaplavených během povodňových událostí a následně opuštěných. Obdobnou genezi lze připsat i svrchnímu korytu. Existence bazálního štěrkového lagu (facie $\mathrm{Gm}$ ), ostře oddělujícího FA2 od starší FA1, vylučuje možnost postupného vyplňování jednoho koryta a tím pozvolný vývoj ze stadia trakčně-saltační poproudové a laterální sedimentace $\mathrm{v}$ aktivním říčním korytě do stadia jezera $\mathrm{v}$ opuštěném korytě (Bridge et al. 1986). Mezi depozicí obou asociací nastala povodňová událost, která reorganizovala koryta a valy na výplavové plošině. Avulzí došlo k výraznějšímu oddělení nově definovaného koryta 2 od hlavních koryt v aktivní osní části plošiny (Pisarska-Jamroży, Zieliński 2014). Důsledkem této změny rychle poklesla energie proudění a nastal bezprostřední přechod $\mathrm{z}$ vysokého proudového režimu (intenzivní eroze, zarovnávání dna koryta, akumulace lagu facie Gm) do slabého proudového režimu se sedimentací nízkých 3-D dnových forem (facie St, Sr). Mezi lagem a drobnými dnovými formami zcela chybí stadium mezoforem (dnové formy vysoké desítky cm, Zieliński 1992), což odráží náhlý pokles proudění. Nízce energetická saltační sedimentace pak rychle přešla do písčito-siltové, a nakonec siltové sedimentace $\mathrm{z}$ klidné, stojaté vody.

Koryto 2 si ve vztahu k hlavním korytům uchovalo velmi distální pozici i po opětovném zaplavení aktivně proudící vodou. Záznamem obnovené aktivity je FA3. Povrch glacilakustrinních sedimentů se stal relativně

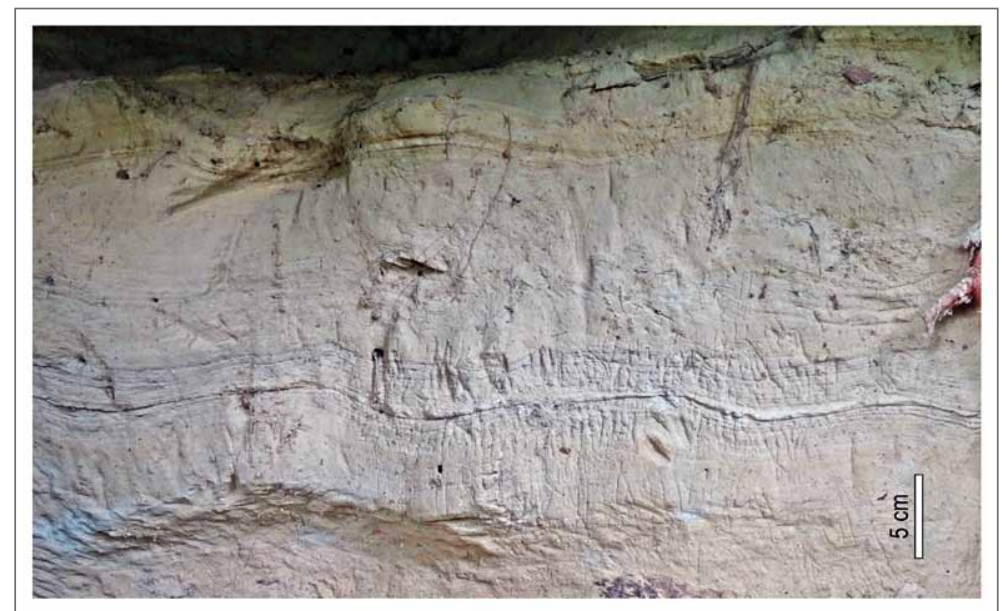

Obr. 4: Zvlněná laminace glacilakustrinních siltů v nadloží glacifluviálních uloženin. Stará kaolínová jáma.

Fig. 4: Wavy laminated glaciolacustrine silt on the top of glaciofluvial deposits. Old Kaolin Mine. 
rovným a plochým dnem koryta, hostícího mělké rameno divočícího toku. Hloubka ramene umožňovala pouze vývoj nízkých a protáhlých dnových forem za podmínek „upper plane bed“ (facie Sh, Miall 1996; Bridge 2003), občas přerušovaných epizodami zklidnění proudění a depozice drobných čeřin nízkého proudového režimu (facie Sr). Reorganizace svrchního koryta vưči spodnímu korytu se odrazila i v odlišném, zjz. směru akrece mírně ukloněných, plochých lavic.

\section{Paleogeografický kontext}

Textury i provenience sedimentů na Polském kopci jsou velmi podobné sedimentům ve Staré kaolínové jámě, která je od Polského kopce vzdálena přibližně $850 \mathrm{~m}$ jz směrem. Ve Staré kaolínové jámě byl v nadloží kaolínu odkryt tento vrstevní sled o mocnosti $\sim 11 \mathrm{~m}$ : prrímo na kaolínu leží štěrkovito-balvanité reziduum (relikt subglaciálního tillu), nad reziduem spočívají glacifluviální sedimenty a nejvýše, pod povrchem terénu, jsou glacilakustrinní silty (Gába 1992; Hanáček 2008, 2017). Glacifluviální sedimenty tvoří šikmo korytovitě zvrstvené písky a štěrky s dominujícími klasty rychlebských hornin, ale současně velmi početnými eratiky (až 32 \%). Glacilakustrinní facie byly horizontálně i zvlněně laminované nebo masivní a neobsahovaly vtroušené větší klasty (nepublikovaná archivní fotodokumentace F. Kieglera, Gába 1992, obr. 4). Nadmořská výška glacilakustrinních horizontů na obou lokalitách je podobná a to $275 \mathrm{~m}$.

Jemnozrnné intraklasty v FA1 na Polském kopci dokazují, že podmínky vhodné pro lakustrinní režim vznikaly a zanikaly opakovaně. To by dokazovalo genetickou vazbu jezírek na koryta zatopená během povodní a opuštěná po opadu záplavy (Pisarska-Jamroży, Zieliński 2014). Nápadná podobnost v charakterech sedimentů a nadmořských výšek glacilakustrinních horizontů na Polském kopci i ve Staré kaolínové jámě ovšem svědčí o velmi podobném vývoji na obou lokalitách. Na výplavové plošině mohlo vzniknout relativně rozlehlé jezero dlouhé nejméně $850 \mathrm{~m}$ (vzdálenost obou lokalit), byt podle mocností glacilakustrinních facií poměrně mělké. Též mohlo jít i o soustavu několika menších jezer vzniklých ve stejnou dobu a za shodných okolností. Pokud jihovýchodně od Vidnavy existovalo v určitou dobu jedno jezero nebo soustava menších jezer, nemohly glacilakustrinní facie vzniknout jen jako výplně dílčích opuštěných koryt po individuálních povodních, ale vznikly důsledkem povodňové události, která reorganizovala výplavovou plošinu jako celek a představuje samostatnou etapu jejího vývoje.

Vidnavská glacifluviálně-glacilakustrinní výplavová plošina byla vymezena z JZ pozvolna se zvedajícím povrchem žulovského masivu a ze S okrajem ledovcového štítu. Stejně vymezené a různě orientované výplavové plošiny $s$ divočícími a vzácně meandrujícími fluviálními koryty a někdy i epizodickými jezery byly pospány rovněž z jiných lokalit severního předpolí Sudet (Brodzikowski, van Loon 1991; Krzyszkowski, Ibek 1996; Nývlt 2008; Salamon 2008; Pisarska-Jamroży et al. 2010). Pokud by se u Vidnavy jednalo o jedno rozsáhlé jezero, nemusely by se nutně na veškeré ploše jeho dna vyskytovat dropstony a dumpstony. Ty bývají nejhojnější především podél kontaktní zóny jezera s ledovcem (Hambrey 1994). Scénář s několika menšími jezery by dropstony a dumpstony omezoval pouze na jezera př́mo ve styku s ledovcem. Na základě pozice glacifluviálně-glacilakustrinní sekvence v nadloží reliktu subglaciálních tillů ve Staré kaolínové jámě (Hanáček 2017) lze usuzovat, že výplavová plošina existovala během ústupu ledovcového štítu. Zdrojem klastů byly jak bazální zóny ledovce nabohacené o provenienčně rychlebský materiál, který byl redeponován ledovcem z preglaciálních podhorských aluviálně-fluviálních uloženin (tento původ dokazuje převaha dobrého zaoblení i vztah ke geologické stavbě regionu, Hanáček 2014), tak i vnitřní zóny ledovce dodávající většinu eratik. Jezerní etapa nebyla finálním stadiem evoluce výplavové plošiny. Popis a interpretaci nadložních částí akumulace do nadmořské výšky $310 \mathrm{~m}$ však limituje velmi špatné a nesouvislé odhalení sedimentů v př́ležitostných odkryvech.

\section{Závěry}

V bývalé pískovně na jižním svahu „Polského kopce“ jv. od Vidnavy jsou odkryty glacifluviální a glacilakustrinní sedimenty výplavové plošiny ústupové fáze pleistocenního kontinentálního zalednění. Profil v pískovně zachycuje výplně dvou koryt v superpozici. Báze obou koryt jsou definovány štěrkovými lagy. Výplň spodního koryta tvoří saltačně-trakční sedimenty poproudově akretujících 3-D dun a laterálně akretujícího postranního valu. Výplň svrchního koryta tvoří saltační sedimenty poproudově akretujících drobných dun a A-čeřin, které do nadloží přecházejí do saltačně-suspenzních sedimentů prríkře až vertikálně agradujících $\mathrm{B}$ - a C-čeřin a poté do čistě suspenzní sedimentace z klidné vody. Jedná se o typickou nahoru zjemňující sekvenci, archivující změnu z fluviálních do lakustrinních podmínek. Bazální štěrkovýlag v podloží této sekvence naznačuje, že vznik jezera následoval povodňovou událost na výplavové plošině. Nejvyšší zachovalou část výplně svrchního koryta tvoří facie plochých lavic, které jsou opět glacifluviální geneze.

Sedimenty na lokalitě Polský kopec jsou velmi podobné sedimentům v nedaleké Staré kaolínové jámě. Obě lokality nejpravděpodobněji tvoří výplň stejného depocentra, kterým byla výplavová plošina omezená z JZ žulovským masivem a ze S okrajem ledovcového štítu. V určité fázi vývoje se na této plošině rozkládalo relativně rozlehlé jezero nebo soustava menších jezer.

\section{Poděkování}

Př́spěvek vznikl v rámci výzkumné činnosti Vlastivědného muzea Jesenicka (VMJ_GEO_KV). Výzkum byl rovněž podpořen projektem ECOPOLARIS, číslo CZ.02.1.01/0.0/ 0.0/16_013/0001708 financovaném Ministerstvem školství, mládeže a tělovýchovy České republiky. Recenzetům, Janu Petríkovi a Danielu Nývltovi (oba Masarykova univerzita) děkujeme za připomínky, které pomohly zvýšit úroveň rukopisu. 


\section{Literatura}

Blažauskas, N., Jurgaitis, A., Šinkūnas, P. (2007). Patterns of Late Pleistocene proglacial fluvial sedimentation in the SE Lithuanian Plain. - Sedimentary Geology, 193, 193-201. https://doi.org/10.1016/j.sedgeo.2005.06.015

Bridge, J. S. (2003). Rivers and Floodplains. - Blackwell Publishing. $490 \mathrm{s.}$

Bridge, J., Collier, R., Alexanders, J. (1998). Large-scale structure of Calamus River deposits (Nebraska, USA) revealed using ground-penetrating radar. - Sedimentology, 45, 977-986. https://doi.org/10.1046/j.1365-3091.1998.00174.x

Bridge, J. S., Smith, N. D., Trent, F., Gabel, S. L., Bernstein, P. (1986). Sedimentology and morphology of a low-sinuosity river: Calamus River, Nebraska Sand Hills. - Sedimentology, 33, 851-870. https://doi.org/10.1111/j.1365-3091.1986.tb00987.x

Bristow, C. (1996). Reconstructing Fluvial Channel Morphology from Sedimentary Sequences. - In: Carling, P. A., Dawson, M. R. (eds). Advances in Fluvial Dynamics and Stratigraphy, 351-371, John Wiley \& Sons. Ltd.

Brodzikowski, K., Van Loon, A. J. (1991). Glacigenic Sediments - Elsevier. 674 s.

Colombera, L., Mountney, N. P., McCaffrey, W. D. (2013). A quantitative approach to fluvial facies models: Methods and example results. - Sedimentology, 60, 1526-1558.

https://doi.org/10.1111/sed.12050

Gába, Z. (1974). Valounové analýzy ledovcových uloženin na Jesenicku. - Časopis Slezského Muzea Opava (A), 23, 49-56.

Gába, Z. (1992). Profil ledovcovými uloženinami u Vidnavy ve Slezsku. - Časopis Slezského muzea (A), 41, 167-172.

Gába, Z., Pek, I. (1999). Ledovcové souvky moravskoslezské oblasti. - Okresní vlastivědné muzeum v Šumperku. Šumperk. 111 s.

Gibbard, P. (1980). The origin of stratified Catfish Creek Till by basal melting. - Boreas, 9, 71-85. https://doi.org/10.1111/j.1502-3885.1980.tb01026.x

Hambrey, M. J. (1994). Glacial Environments. - UCL Press. London. 296 s.

Hanáček, M. (2008). Valounové analýzy glacifluviálních sedimentů na lokalitě Stará kaolínová jáma u Vidnavy na Jesenicku. Časopis Slezského zemského muzea (A), 57, 222-236.

Hanáček, M. (2014). Význam valounových analýz ledovcových sedimentů pro paleogeografické rekonstrukce pleistocenního kontinentálního zalednění Jesenicka. - Geologické výzkumy na Moravě a ve Slezsku, 21, 17-24. https://doi.org/10.5817/ GVMS2014-1-2-17

Hanáček, M. (2017). Vztah mezi výskytem balvanů v ledovcových sedimentech a charakterem preglaciálního podloží v předpolí Rychlebských hor a ve Zlatohorské vrchovině. - Geologické výzkumy na Moravě a ve Slezsku, 24, 13-20. https://doi. org/10.5817/GVMS2017-1-2-13

Hanáček, M., Engel, Z., Procházková, B. (2016). Vývoj ledovcových sedimentů na kontaktu s žulovským masivem ve Štachlovicích u Vidnavy. - Geologické výzkumy na Moravě a ve Slezsku, 23, 13-23. https://doi.org/10.5817/GVMS2016-1-2-13

Jopling, A. V., Walker, R. G. (1968). Morphology and origin of ripple-drift cross-lamination, with examples from the Pleistocene of Massachusetts. - Journal of Sedimentary Research, 38, 971-984. https://doi.org/10.1306/74D71ADC-2B21-11D7$-8648000102 \mathrm{C} 1865 \mathrm{D}$

Kiegler, F. (1938). Erdgeschichte des Weidenauer Ländchens. - Weidenau.

Krzyszkowski, D., Ibek, M. (1996). Middle Pleistocene sedimentation and palaeogeography of the Dzierżoniów Basin, Sudetic Foreland, Southwestern Poland. - Annales Societatis Geologorum Poloniae, 66, 35-58.

Miall, A. D. (1977). A Review of the Braided-River Depositional Environment. - Earth-Science Reviews, 13, 1-62. https://doi. org/10.1016/0012-8252(77)90055-1

Miall, A. D. (1985). Architectural-Element Analysis: A New Method of Facies Analysis Applied to Fluvial Deposits. - Earth-Science Reviews, 22, 261-308. https://doi.org/10.1016/0012-8252(85)90001-7

Miall, A. D. (1996). The Geology of Fluvial Deposits. Sedimentary Facies, Basin Analysis, and Petroleum Geology. - Springer. 582 s.

Nývlt, D. (2008). Paleogeografická rekonstrukce kontinentálního zalednění Šluknovské pahorkatiny. - MS, disertační práce. Př́rodovědecká fakulty Univerzity Karlovy. Praha.

Nývlt, D., Engel, Z., Tyráček, J. (2011). Pleistocene glaciations of Czechia. - In: Ehlers J., Gibbard P. L., Hughes P. D. (eds): Quaternary Glaciations - Extent and Chronology Part IV - a closer look. Developments in Quaternary Science, 37-46, Elsevier. https://doi.org/10.1016/B978-0-444-53447-7.00004-0

Pisarska-Jamroży, M. (2015). Factors controlling sedimentation in the Toruń-Eberswalde ice-marginal valley during the Pomeranian phase of the Weichselian glaciation: an overview. - Geologos, 21, 1-29. https://doi.org/10.1515/logos-2015-0001

Pisarska-Jamroży, M., Machowiak, K., Krzyszkowski, D. (2010). Sedimentation style of a Pleistocene kame terrace from the Western Sudety Mountains, S Poland. - Geologos, 16, 101-110. https://doi.org/10.2478/v10118-009-0008-8

Pisarska-Jamroży, M., Van Loon, A. J., Bronikowska, M. (2018). Dumpstones as records of overturning ice rafts in a Weichselian proglacial lake (Rügen Island, NE Germany). Geological Quarterly, 62, 917-924. https://doi.org/10.7306/gq.1448

Pisarska-Jamroży, M., Zieliński, T. (2014). Pleistocene sandur rhythms, cycles and megacycles: Interpretation of depositional scenarios and palaeoenvironmental conditions. Boreas, 43, 330-348. https://doi.org/10.1111/bor.12041

Powers, M. C. (1953). A new roundness scale for sedimentary particles. - Journal of Sedimentary Petrology, 23, 117-119. https:// doi.org/10.1306/D4269567-2B26-11D7-8648000102C1865D

Salamon, T. (2008). Origin of Pleistocene outwash plains in various topographic settings, southern Poland. - Boreas, 38, $362-378$. https://doi.org/10.1111/j.1502-3885.2008.00049.x

Smith, N. D. (1974). Sedimentology and bar formation in the Upper Kicking Horse River, a braided outwash stream. - Journal of Geology, 82, 205-223. https://doi.org/10.1086/627959

Wentworth, C. K. (1922). A scale of grade and class terms for clastic sediments. - Journal of Geology, 30, 377-392.

Zielinski, T. (1989). Lithofacies and palaeoenvironmental characteristics of the Suwałki outwash (Pleistocene, Northeast Poland). Annales Societatis Geologorum Poloniae, 59, 249-270.

Zielinski, T. (1992). Proglacial valley facies of the Silesian Upland - Genetic factors and their sedimentological effects. - Geologica Sudetica, 26, 83-118. 
Zielinski, T. (1993). Sandry Polski północno-wschodniej - osady i warunki sedymentacji. - Uniwersytet Śląski. Katowice. 96 s. Zielinski, T., Van Loon, A. J. (2003). Pleistocene sandur deposits represent braidplains, not alluvial fans. - Boreas, 32, 590-611. https://doi.org/10.1111/j.1502-3885.2003.tb01238.x

Žáček, V., Čurda, J., Kočandrle, J., Nekovařík, Č., Nývlt, D., Pecina, V., Skácelová, D., Skácelová, Z., Večeřa, J. (2004). Základní geologická mapa České republiky 1 : 25000 list 14-222 Vidnava s Vysvětlivkami. - Česká geologická služba. Praha. 